\title{
Література
}

1. Березівська Л. Освітньо-виховна діяльність київських просвітницьких товариств (друга половина XIX - поч. XX ст.) / Л. Березівська. - К. : Молодь. - 1999. 192 с. 2. Грінченко М. Колись і тепер / М. Грінченко // IP НБУ ім. В. Вернадського НАН України, ф. I, спр.32547, 14 арк. 3. Грінченко М. Про заборону викладання української мови в школі / М. Грінченко // ІР НБУВ, ф. I, спр.32571, 14 арк. 4. Державна національна програма «Освіта» («Україна ХХІ століття») // Освіта. - 1993. - № 44 - 46. С. 1-13. 5. Думанська М. Організаційно-видавничі та редакторські аспекти діяльності Марії Грінченко : автореф. дис... канд. наук із соц. комунікацій / М. Думанська. Запоріжжя, 2010. - 18 с. 6. Загірня М. Спогади / М. Загірня; упоряд., передм., прим. Л. Л. Неживої - Луганськ: Шлях, 1999. - 160 с. 7. Закон України про внесення змін і доповнень до закону Української РСР «Про освіту». - К. : ГЕНЕЗА, 1996. - 36 с. 8. Національна доктрина розвитку освіти України у XXI столітті. - К. : Шкіл. світ, 2001. - 23 с. 9. Нежива Л. Марія Загірня : літер. портрет / Л. Нежива. - Луганськ : Знання, 2003. $-170 \mathrm{c}$.

УДК 37(477)

Ольга Рудь

\section{ФОРМУВАННЯ ОСОБИСТОСТІ МАЙБУТНІХ ПЕДАГОГІВ У ХРЕСТОВОЗДВИЖЕНСЬКОМУ ТРУДОВОМУ БРАТСТВІ МИКОЛИ НЕПЛЮЄВА}

Рудь О. М. Формування особистості майбутніх педагогів у Хрестовоздвиженському Трудовому Братстві Миколи Неплюєва.

У статті проаналізовано систему навчання і виховання Миколи Неплюєва, виявлено особливості формування особистості майбутнього педагога у Хрестовоздвиженському Трудовому Братстві.

Ключові слова: Хрестовоздвиженське Трудове Братство, формування особистості педагога-майстра, естетичне виховання, релігійне виховання, моральне виховання, розумовий розвиток.

Рудь О. Н. Формирование личности будущих педагогов в Крестовоздвиженском Трудовом Братстве Николая Неплюева.

В статье проанализирована система обучения и воспитания Николая Неплюева, обнаружены особенности формирования личности будущего педагога в Крестовоздвиженском Трудовом Братстве.

Ключевые слова: Крестовоздвиженское Трудовое Братство, формирование личности педагога-мастера, эстетичное воспитание, религиозное воспитание, моральное воспитание, умственное развитие.

Rud O.N. The future teacher personality forming in Krestovozdvizhensk Labour Fraternity of Nickolay Neplyuev.

The article deals with the educational system of Nickolay Neplyuev The features of future teacher personality forming in Krestovozdvizhensk Labour Fraternity are found out.

Key words: Krestovozdvizhensk Labour Fraternity, future teacher personality forming, aesthetic education, religious education, moral education, mental development.

На сучасному етапі розвитку суспільства постає питання про підготовку висококваліфікованого вчителя, здатного в умовах масової освіти забезпечувати 
високий рівень навчання та виховання учнів. Від особистості вчителя, рівня його професійно-педагогічних умінь та здібностей залежить ефективність педагогічної діяльності. Учитель має володіти сучасними педагогічними технологіями, що забезпечують розвиток учня, стимулюють його потребу в саморозвитку і самореалізації.

Професійна майстерність учителя певною мірою залежить від тих умов і середовища, у яких формувалася його особистість, найбілыш цінні якості майбутнього педагога. Пошук оптимальних шляхів ефективної професійно-педагогічної підготовки вчителя на сучасному етапі вимагає всебічного ретроспективного аналізу основних тенденцій формування особистості вчителя у вітчизняній педагогіці.

Аналіз сучасного стану досліджень і практики педагогічної освіти свідчить про зростаючий інтерес до проблеми формування особистості вчителя. Різні аспекти професійної підготовки майбутнього педагога в системі неперервної професійної освіти розкриваються у працях І. Беха, С. Гончаренка, В. Гриньової, М. Свтуха, В. Кан-Калика, А. Капської, Л. Карамушки, Н. Ничкало, В. Орлова, В. Пікельної, П. Підкасистого, О. Савченко, С. Сисоєвої, О. Семеног, Л. Хомич та інших. Основним тенденціям розвитку професійно-педагогічної підготовки вчителя в Україні на різних етапах історичного розвитку присвячені наукові роботи таких науковців, як А. Алексюк, Л. Вовк, Н. Дем’яненко, Т. Завгородня, Н. Камниченко, О. Лавріненко, І. Лікарчук, В. Луговий, В. Майборода, М. Микитюк, Т. Слободянюк, О. Сухомлинська, М. Ярмаченко.

Вивченню українських педагогічних персоналій як виразників думки і практики своєї епохи, визначенню їх унеску в розбудову системи професійної підготовки майбутніх учителів та саморозвитку педагогічної майстерності присвячені праці Н. Антонець, А. Бойко, С. Грищенко, Н. Демченко, О. Дутко, Н. Сфименко, І. Киричок, О. Кравченко, А. Луцюка, Л. Нечипоренко, О. Сухомлинської, О. Таран, Т. Усатенко, О. Щербакової.

Відомою i непересічною постанню кінця XIX - початку XX століття був науковець, педагог, засновник Хрестовоздвиженського Трудового Братства Микола Неплюєв. Окремі питання його життєвого і творчого шляху висвітлено в дослідженнях В. Авдасьова, Н. Будаговської, В. Клюєвої, Б. Ковальова, Н. Ковальової, О. Колотило, I. Куліш-Лукашевич, С. Майданової, А. Павленко, О. Попова, О. Потапової, В. Терехової, Л. Федоренко та ін.

Мета статmі- виявити особливості формування особистості майбутнього педагога у Хрестовоздвиженському Трудовому Братстві Миколи Неплюєва (18891929 pp.).

Микола Миколайович Неплюєв народився 11 вересня 1851 року в містечку Ямпіль Глухівського повіту Чернігівської губернії (тепер - районний центр Сумської області). Уже в ранньому дитинстві Микола Неплюєв - син дійсного таємного радника, предводителя дворянства Чернігівської губернії Миколи Івановича Неплюєва і внучки відомого воєначальника Карла XII, баронеси Шліппенбах Олександри Миколаївни виявив глибоку релігійність. Його настільною книгою стала Євангелія, читати яку кожен ранок і вечір стало для нього духовною потребою, як і молитися [4, с. 5].

Після закінчення юридичного факультету Петербурзького університету i трьохрічної дипломатичної служби в складі російського посольства в Мюнхені, Микола Неплюєв прийшов до твердого переконання: «покласти всі сили розумові, моральні і матеріальні на справу чесної злагоди життя і віри - очевидний елементарний обов'язок щиро віруючого християнина» [4, с. 31]. Він приймає рішення піти «до тих бідних дітей народу, які нуждаються в мені у всіх відношеннях, яких лише потрібно навчити думати і відчувати по-християнськи, щоб віра їх із сліпої стала свідомою, з якими можна буде за заповіддю Христа Спасителя жити в одностайності i однодумності любовного 
братського спілкування» [4, с. 30]. Микола Неплюєв залишає дипломатичну службу, закінчує Петровську сільськогосподарську академію і оселяється в своєму родовому маєтку. Молодий дворянин назавжди пориває зі світським життям.

У серпні 1881 року М. Неплюєв бере на виховання десять селянських дітей і відкриває притулок, який через чотири роки був реорганізований у чоловічу сільськогосподарську школу. Офіційне відкриття Воздвиженської сільськогосподарської школи відбулося 4 серпня 1885 року. Пізніше, у 1891 році, було відкрито Преображенську жіночу сільськогосподарську школу.

Перші випускники Воздвиженської сільськогосподарської школи, не бажаючи розлучатися зі своїми вчителями, сформували в 1889 році спільноту, що надало початок Хрестовоздвиженському Трудовому Братству.

Особливістю в організації Трудового Братства були братські гуртки - «Старший Братський Гурток» і «Молодший Братський Гурток». Метою «Старшого Братського Гуртка» було об'єднання кращих сил школи і організація справи доброго, морального впливу на молодших і більш слабких товаришів. Кожному гуртківцю доручалося виховання чотирьох-п’ятьох членів «Молодшого Братського Гуртка», завдання якого «організація добра в житті школи, об'єднання дітей доброї волі, створення для них здорової духовної атмосфери, у якій їм дихалося б вільно і була б можливість надати один одному моральну підтримку» [4, с. 176]. Були у Трудовому Братстві і «позагурткові», яких «братчики» намагалися залучити до гуртків.

Микола Неплюєв дбав про створення міцного педагогічного колективу однодумців. На прохання Миколи Миколайовича, у 1888 році школі було «даровано право мати учителів із своїх же колишніх учнів, і цим зроблений великий крок в успішному веденні справи» [2, с. 169].

Три перші вихованці М. Неплюєва стали дійсно його сподвижниками у всіх починаннях. Андрій Іванович Фурсей навчав учнів старших класів землеробству, був управляючим Воздвиженського маєтку, виконував обов'язки управляючого школою. Федір Юхимович Чвертка викладав скотарство і ветеринарію, Ілля Павлович Кобець був учителем першого підготовчого класу. Пізніше у 1894 році М. Неплюєв напише: «Нині всі місця викладачів ... зайняті людьми, що закінчили курс нашої ж школи, які були ще в школі моїми помічниками в справі морального виховання товаришів, членами Трудового Братства, людьми, готовими віддати прийнятій на себе справі все життя, які гаряче люблять школу, вважають радість свою в самовідданому служінні на користь вихованців» [4, с. 102]. На той час у школах Хрестовоздвиженського Трудового Братства, крім перших випускників, працювали Тихон Павлович Макушенко, який викладав землеробство і співи, скотарство і ветеринарія читав Федір Юхимович Чвертка, математику і геодезію - Микола Іванович Івченко, гімнастику - Сергій Павлович Свириденко, викладачем підготовчого класу був Іван Федорович Куліш. Всі вони закінчили курс Воздвиженської школи. За словами М. Неплюєва, «ніколи до того школа не мала викладачів краще підготовлених до виконання своїх обов'язків і так добросовісно їх виконуючих» [4, с. 102].

Засновник Трудового Братства переслідував мету дати не лише спеціальні знання, але забезпечити високий культурний рівень особистості, виховати педагогів, які будуть «турбуватися про християнське виховання дітей в дусі православ'я, привчати їх думати, відчувати i жити відповідно до вчення Христа Спасителя i уставів святої церкви» [2, с. 170]. Формування особистості майбутнього вчителя-майстра розпочиналося 3 перших днів перебування молодої людини в школах Трудового Братства. 
До школи за результатами вступних випробувань 3 російської мови, читання i арифметики приймалися діти 12-17 років усіх віросповідань. Курс навчання був розрахований на п'ять років. Протягом перших трьох років учні одержували загальноосвітню i загальну сільськогосподарську підготовку, останні два роки поглиблено вивчали профільні предмети. Учні одержували спеціалізацію за інтересами, відпрацьовували навички в організації сільськогосподарського виробництва й управлінні ним. В атестаті випускника вказувалася галузь сільського господарства, у якій учень показав найкращі знання і вміння.

У школах Трудового Братства, навчання в яких було безкоштовним, вихованці одержували міцні різнобічні знання. Тут викладалися російська мова 3 чистописанням, географія, російська історія, арифметика, геометрія, фізика, елементарна хімія, анатомія і фізіологія, сільськогосподарська ентомологія, ботаніка, законодавство, бджолярство, зоотехнія, молочна справа, основи ветеринарії, землеробство із садівництвом, скотарство, агрономія, лісове господарство, короткі відомості з сільськогосподарської економії і рахівництва, креслення, співи, гімнастика. Крім того, дівчатка вивчали птахівництво, рукоділля та домоводство [4, с. 12].

Від учителів М. Неплюєв вимагав, щоб «уроки їх мали характер безпосереднього керівництва учнями під час вивчення відомого предмета і мали більш практичне, життєве значення для них» [4, с. 95]. Практичні заняття проходили на полі, в саду, лісових розсадниках, на конюшнях, фермах, на пасіці, у слюсарній і столярній майстернях. Вихованці працювали в дитячих садках і притулках. Узимку вчителі організовували демонстративні екскурсії зі своєї спеціальності. Виховна система навчальних закладів М. Неплюєва формувалася на любові до праці, дбайливому ставленні до її результатів [5].

Педагог намагався виховати в учнів почуття колективізму, розвинути спільну діяльність і взаємодопомогу. У школі існувала практика спільної підготовки уроків цілим класом (за винятком усіх письмових робіт і вивчення матеріалу напам'ять). Колективна підготовка уроків мала свої переваги: 1) учні привчалися до дружної спільної діяльності; 2) вихованці мали можливість систематично користуватися допомогою більш здібних однокласників, що виключало механічне засвоєння уроків; 3) жива розповідь вивченого, пояснення незрозумілого краще сприймалися 3 вуст товариша, ніж матеріал з книжки; 4) спільна робота заставляла ледарів і незосереджених «пробуджуватися від духовної сплячки», «збуджувала енергію духу і допитливість розуму». Для більш здібних учнів це була своєрідна педагогічна практика, під час якої вони мали забезпечити ясність розповіді, виокремити головне, значуще, пояснити незрозуміле. У результаті учні стали навчатися стабільніше, загальний рівень занять значно підвищився [2, с. 182].

Розумовий розвиток учнів, на думку М. Неплюєва, є елементарним обов'язком кожної християнської школи [4, с. 129]. Задля цього в трудовому братстві проходили колективні читання книг святих отців і проповідників, бесіди, метою яких було обговорення всіх життєвих питань 3 погляду віри і життя за вірою, реферати, під час яких старшокласники привчалися систематизувати свої думки 3 окремих питань i зв'язно їх викладати. Деякі реферати складалися систематично задля поступового викладу історії церкви, загальної історії і російської літератури, предметів, які не входили до шкільної програми.

Учні мали змогу користуватися шкільною бібліотекою, яка нараховувала 6000 томів, і трьома відділами особистої бібліотеки Миколи Неплюєва - богословським, історичним і науковим. Це сприяло розвитку в учнів бажання займатися пошуковою 
діяльністю, поглиблено вивчати окремі предмети, створювало реальні можливостей для набуття учнями знань, умінь та практичного досвіду написання наукової роботи.

Науково-дослідницькій діяльності учнів сприяли часті зустрічі із відомими науковцями, які виступали перед ними 3 доповідями про російських i іноземних письменників.

Значна увага в трудовому братстві приділялася естетичному вихованню учнів. Музику викладала рідна сестра Миколи Неплюєва Ольга Миколаївна, яка здобула спеціальну освіту в Санкт-Петербурзі, пройшла курс вокалу у відомої італійської співачки Репетто. На уроках учні вивчали нотну грамоту, гами, 8 церковних гласів, постановку голосу та дихання, готувала сольні номери. Ольга Неплюєва вчила дітей грі на фортепіано.

Виховання і розвиток учнів здійснювався на прикладі високих зразків творів культури. М. Неплюєв часто запрошував учнів до себе додому, де грав на фортепіано вибрані музичні твори Бетховена, Моцарта, Шуберта, а також власні твори, яких нараховується понад 237. Крім цього, він поклав на ноти сім віршів О. Хомякова, три молитви для хорового співу.

Хор Трудового Братства виступав на музичних вечорах, у його виконанні звучали класичні народні твори. Хор часто співав у різних церквах. Під час паломницької поїздки до Києва в 1891 році хористи Трудового Братства мали можливість співати в Софійському соборі.

До педагогічного процесу залучалися видатні музиканти. Викладачем класу скрипки була відома артистка Міттельштед-Голлас. Діти тягнулися до музичних інструментів, у власному симфонічному оркестрі грали твори Чайковського, Березовського, перський марш і марш гладіаторів, виконували вальси. У виконанні оркестру народних інструментів звучали українські й російські народні пісні.

Формуванню світогляду, художнього смаку, розвитку творчої особистості вихованців сприяли уроки малювання рідної сестри М. Неплюєва Марії Миколаївни Уманець, учениці відомого живописця-пейзажиста А. Мещерського, яка працювала в жанрі вазописі та мініатюри.

У Воздвиженському Трудовому Братстві плідно працював літературний гурток, твори його учасників друкувалися в шкільному журналі «Луч», потрапляли на сторінки загальноросійських видань.

Для підтримки фізичної бадьорості, розвитку спритності і витонченості рухів учні займалися гімнастикою, стройовим маршем на відкритому повітрі, практикувалися «фізичні втіхи».

3 великою любов’ю і благоговінням М. Неплюєв відвідував свою школу, вважав іiі храмом, де відбувається таїнство переродження душі. У школі учні вивчали Закон Божий, до програми якого входив короткий катехізис, православне богослужіння, важливі події із церковної історії.

Виховання «братолюбивих» стосунків підтримувалося особливою, відмінною від офіційної, системою релігійного життя. Крім звичайних канонічних правил, у Воздвиженську були введені з дозволу єпископа Чернігівського і Ніжинського Сергія деякі додаткові звичаї: М. Неплюєв одержав унікальне право вдягатися в стихар і виголошувати 3 церковного амвона власні проповіді і проповіді членів Братства. Богослужіння супроводжувалося співом братського хору, на свята М. Неплюєв виконував власні релігійні музичні композиції.

У Трудовому Братстві була продумана i чітко організована система самоуправління вихованців. Всі види обов'язкових робіт розподілялися по класах. Вихованці другого спеціального класу призначалися черговими при управляючому 
школою. До їх обов'язків входило ведення табелів і облік роботи, вони стежили за ходом робіт, надавали управляючому проект наряду на наступний день, привчаючись таким чином до самостійної господарської діяльності.

Засобами стимулювання вихованців до самовиховання були щосуботні збори: «круг»- 3 учителями, «товариські збори» - без учителів. На них обговорювалося життя школи за тиждень, розглядалися потреби школи, про які міг говорити кожний. Такі збори мали за мету «збудити вільну волю і совість в учнів», привчити їх до свідомої самодисципліни, постійного самоконтролю, оцінки себе й інших, що $є$ важливим для майбутніх педагогів.

Після закінчення навчання здібні до педагогічної діяльності вихованці під керівництвом М. Неплюєва протягом року готувалися до вчительської роботи, складали відповідні екзамени у Глухівській гімназії.

Показником ефективності педагогічної діяльності М. Неплюєва щодо формування особистості вчителя-майстра є подальша доля вихованців його шкіл.

Іван Спиридонович Абрамов після закінчення навчання в Хрестовоздвиженському Трудовому Братстві склав екзамени на звання сільського вчителя. Спочатку викладав при школі у тому ж Воздвиженську, а потім - у селі Студенок Глухівського повіту. Пізніше I. С. Абрамов став членом Археологічного товариства, дійсним членом Російського Географічного товариства.

Довгі роки працював учителем біології вихованець Трудового Братства, волинський поет Іван Куліш, який за сумлінну працю в справі виховання молоді нагороджений нагрудним знаком «Відмінник народної освіти».

Займався науковою i педагогічною діяльністю дослідник історії України, письменник Павло Костянтинович Федоренко, який присвятив документальну автобіографічну повість «Серебряные нити» засновнику Трудового Братства М. Неплюєву і людям, які стояли біля його витоків.

Продовжили педагогічні традиції свого наставника випускники Воздвиженської школи Степан Клюєв і його дружина Євдокія Солдатова, які довгий час учителювали в тому ж Воздвиженську.

Система виховання Миколи Неплюєва, яка мала за мету гармонічний розвиток «усіх трьох сторін людської природи»- розумової, фізичної і моральної; глибина і грунтовність знань, які одержували вихованці Хрестовоздвиженського Трудового Братства; спеціальна підготовка до творчої педагогічної діяльності здійснили позитивний вплив на формування особистості педагога-майстра, здатного педагогічно мислити і діяти, вносити життєвість і практичність у справу викладання, виховувати учнів у братерській любові і злагоді.

\section{Література}

1. Авдасьов В. Трудове братство Миколи Неплюєва. Історія і доля унікальної моделі християнської цивілізації / В. Авдасьов // Краєзнавство: науково-методичний та практичний аспекти. Матеріали Краєзнавчої науково-практичної конференції (8-10 червня 2010 р., Суми). - Суми: РВВ: СОІППО, 2010. - С. 8-12. 2. Доклад А. А. Лютецкого, члена-соревнователя Крестовоздвиженского Первого Трудового Братства, учрежденного Н. Н. Неплюевым, о религиозно-нравственном и вообще нравственном воспитании в школах Братства// Министерство Народного Просвещения. - М., 1899. - Вып.1.C. 165-196. 3. Екологічні засади економічного розвитку Хрестовоздвиженського Трудового Братства. Його спадщина i сучасність: [збірник матеріалів/ за ред. В. М. Авдасьова, Н. В. Будаговської, О. В. Поповаї. - Суми: ВД «Фолігрант», 2010. 32 с.: іл. - Текст укр. та рос. мовами. 4. Избранные сочинения Н. Н. Неплюева. Книга I. Сумы: ИД «Фолигрант», 2011. - 288 с.: 74 ил. 5. Ковальова Н. О. Просвітницько- 
педагогічна діяльність Миколи Неплюєва / Н. О. Ковальова // Матеріали IX Всеукраїнської історико-краєзнавчої конференції 3 міжнародною участю (24-25 листопада 2011 р.). - Суми: Вид-во СумДПУ ім. А. С. Макаренка, 2011. - С. 278-282.

УДК 37.091 .4

Олеся Тесцова

\section{ГЕРБЕРТ СПЕНСЕР - ОСНОВОПОЛОЖНИК РЕФОРМАТОРСЬКОЇ ПЕДАГОГІКИ}

Тесцова О. О. Герберт Спенсер - основоположник реформаторської педагогіки.

Стаття висвітлює характерну рису видатного англійського філософа і науковця Герберта Спенсера як одного з ідейних основоположників реформаторської педагогіки. Зокрема, розглядається місце принципу свободи у його виховній системі; розкривається питання дисципліни задля усунення штучних покарань, особливу увагу звернено на виховний потенціал родинної системи виховання.

Ключові слова: Г. Спенсер, виховна система, інновації у виховній системі, принципи свободи у вихованні, шкільний предмет у виховній системі.

Тесцова А. А. Герберт Спенсер - основоположник реформаторской педагогики.

Статья расскрывает характерную особенность известного английского философа и ученого Герберта Спенсера как одного из идейных основоположников реформаторской педагогики. В частности, рассматривается место принципа свободы в его воспитательной системе; раскрывается вопрос дисциплины для предупреждения нецелесообразных наказаний, особенное внимание обращено на воспитательный потенциал семейной системы воспитания.

Ключевые слова: Г. Спенсер, воспитательная система, инновации в воспитательной системе, принципы свободы в воспитании, школьный предмет в воспитательной системе.

Testsova A. A. Herbert Spencer - founder reform pedagogy.

Article revealing a characteristic feature of the famous English scientist and philosopher Herbert Spencer, as one of the ideological founders of progressive educational. In particular, the position of the principle of freedom in its educational system.

Key words: G. Spencer, the educational system, the principles of freedom in education.

Герберт Спенсер (1820-1903pp.) - один із найбільших інтелектуалів Англії. Д. Фіске бачив у ньому людину рівня Аристотеля й Ньютона, вважаючи, що його твори за широтою задуму перевершують праці цих двох філософів. Г. Джордж писав: «Величезна кількість людей визнає його за найбільш глибокого, оригінального й авторитетного мислителя 3 усіх сучасних нам, з усіх, які жили в XIX ст. і навіть 3 усіх, яких будь-коли бачив світ» [1, c. 1]. Поряд із ним Г. Джордж називав таких поважних науковців, як Д.С. Мілль, Р. Ланкастер, Р. Проктор, Г.Г. Льюіс, Д. Массон, Мек-Кош, Сент-ДжорджМіварт, Тіндаль, Гекслі, Ч. Дарвін, С. Джевонс, Г. Барнард [1, с. 2-3]. Л. Льар називав Г. Спенсера серед найвизначніших англійських реформаторів логіки [2, с. 33].

Відомий російський публіцист І. Шкловський [4, с. 483] у книзі «Англійські силуети» присвятив Г. Спенсеру окрему главу [3, с. 421]. К. Ушинський називав його «видатним мислителем» [5, с. 281], А. Лунк писав, що праці Г. Спенсера охоплюють усе, що було відомо до нього і водночас $є$ вихідним пунктом для безмежних подальших досліджень [3, с. 428]. 